\title{
Target Anatomic Site Code
}

National Cancer Institute

\section{Source}

National Cancer Institute. Target Anatomic Site Code. NCI Thesaurus. Code C93690.

A coded value specifying the anatomic location that is the focus of the entity or activity. 